\title{
REVIEW JURNAL: BIOADSORBEN LIPID PATCH BIJI SALAK (Salaccazalacca) SEBAGAI TERAPI OBESITAS
}

\author{
Asril Burhan ${ }^{1}$, Christien Darwis ${ }^{2}$, Megi Sella Lindang ${ }^{3}$, Muhammad Faris Hidayat $^{4}$ \\ ${ }^{1,2,3,4}$ Sekolah Tinggi Ilmu Farmasi Makassar, Indonesia \\ email: asrilburhan@gmail.com,
}

\begin{abstract}
ABSTRAK
Keberadaan biji salak (Salaccazalacca) sangat melimpah dan mudah didapatkan. Biji salak mengandung selulosa yang dapat digunakan sebagai bioadsorben terhadap minyak jelatah. Pemanfaatan biji salak masih sangat jarang. Penyerapan lemak di usus merupakan salah satu mekanisme dari obat yang digunakan dalam terapi obesitas. Pengaplikasiantransdermalpatch oleh pasien dapat dilakukan dengan mudah serta mencegah zat aktif obat mengalami metabolisme lintas pertama dihati.Review ini bertujuan untuk membahas potensi bioadsorben lipid biji salak dalam sediaan transdermalpatch untuk terapi obesitas, sehingga dapat menambah nilai guna biji salak dan dapat bermanfaat dibidang kesehatan. Penelusuran literatur dilakukan melalui Google Scholar, PubMed, ScienceDirectdan makalah penelitian yang terkait dengan kemampuan bioadsorben lipid biji salak dalam sediaan transdermalpatch. Biji salak mengandung selulosa yang dapat dijadikan biosorben (adsorben) karena adanya gugus - OH yang terikat pada selulosa. Sisi aktif pada bioadsorben biji salak tersebut efektif dalam mengikat gugus fungsi yang terdapat pada minyak jelatah. Transdermalpatch efektif dalam menurunkan volume jaringan adiposa yang diujikan pada tikus yang obesitas. selain itu transdermalpatch juga efektif menurunkan kadar kolesterol total, trigliserida dan lowdensity lipoprotein (LDL) pada tikus yang hiperlipidemia. Dapat disimpulkan bahwa bioadsorben lipid biji salak berpotensi efektif dalam sediaan transdermalpatch.
\end{abstract}

Kata Kunci: Biji salak (Salaccazalacca), Adsorben, Selulosa, MinyakJelatah,Transdermalpatch

\section{PENDAHULUAN}

Keberadaan biji salak sangat melimpah dan mudah didapatkan. Pemanfaatan biji salak (Salaccazalacca) sebagai obat masih jarang dilakukan karena biji salak mempunyai tekstur yang keras dan tidak mudah hancur sehingga untuk mengolahnya cukup sulit. Pada umumnya setelahmengkonsumsi daging buahnya, biji salak akan dibuang karena dianggap sudah tidak bermaanfaat lagi, sehingga akan menjadi limbah. Berdasarkan penelitian yang telah dilakukan oleh Girsang etal. 2015, serbuk biji salakmemiliki daya bioadsorben yang dapat menyerap kolesterol dalam minyak jelatah karena adanya gugus hidroksil dan metil pada serbuk biji salak yang berperan aktif dalam mengikat gugus fungsi pada minyak jelatah. Penelitian tersebut dilakukan dengan memasukkan serbuk biji salak secara langsung kedalam minyak jelatah dan berhasil membuktikan bahwa 
serbuk biji salak mampu menjernihkan minyak tersebut dari warna awalnya yang berwarna hitam pekat(Girsang et al., 2015). Biji salak kaya akan karbohidrat, salah satunya selulosa (Kumoro et al., 2020). Biji salak mengandung selulosa yang dapat digunakan sebagai adsorben. Selulosa mempunyai potensi yang cukup besar untuk dijadikan sebagai adsorben karena gugus hidroksil $(-\mathrm{OH})$ yang terikat dapat berinteraksi dengan komponen adsorbat (Aji dan Kurniawan, 2012; Adisesa, 1993).Dalam pemanfaatannya dibidang kesehatan biji salak pernah diolah menjadi kopi biji salak yang dapat berkhasiat untuk kesehatan(Karta dkk., 2015), namun tentunya untuk mengkonsumsi kopi biji salak tersebut perlu dilakukan penyeduhan terlebih dahulu sehingga dibutuhkan waktu untuk menyeduhnya. Pada sebagian masyarakat khususnya penderita obesitas belum tentu dapat bergerak setiap saat untuk membuatkopibiji salak tersebut karena bobot badannya yang besar. Dengan kondisi berat badan yang berlebih akibat kegemukan, biasanya menyebabkan penderita obesitas kesulitan dan malas untuk melakukan aktivitas fisik, sehingga penderita obesitas lebih sering duduk. Kebiasaan tersebut dapat membuat penderita obesitas semakin gemuk dengan kadar kolesterol yang semakin meningkat didalam plasma sehingga dapat memicu timbulnya penyakit komplikasi lain. Masalah obesitas terus meningkat dan mempengaruhi banyak negara-negara di dunia baik negara maju dan negara berkembang, terutama di perkotaan. Prevalensi obesitas yang terus meningkat menjadi salah satu hal yang dikhawatirkan di Indonesia. Obesitas disebabkan oleh beberapa faktor, diantaranya pola makan berlebih, kurang berolahraga dan faktor lingkungan. Sehingga, terjadi kelebihan kalori didalam tubuh dan kelebihan kalori tersebut akan disimpan dalam bentuk lemak, yang lama kelamaan akan mengakibatkan kegemukan (Budiarso dkk., 2019). Penghambatan penyerapan lemak di usus merupakan salah satu mekanisme dari obat yang digunakan dalam terapi obesitas. Mekanisme ini bertujuan agar lipid tidak diteruskan ke hati untuk dimetabolisme (Tjay dan Rahardja, 2015).

Sistem terapi secara transdermal, merupakan sistem penghantaran obat melalui kulit menggunakan patch. Sistem tersebut dapat mencegah dapat mencegah zat aktif yang berkhasiat obat mengalami metabolisme lintas pertama di hati, pelepasan zat obat terkontrol, 
durasi kerja obat lama serta pengaplikasiannya dapat dilakukan sendiri oleh pasien dengan mudah, selain itu dapat digunakan oleh pasien yang tidak sadar dan pasien yang tidak dapat menggunakan obat secara oral(Ghulaxe and Verma, 2020). Penelitian yang telah dilakukan oleh Ariamoghaddam et al. 2018, menunjukkan bahwa sistem penghantaran bahan obat transdermalpatch terbukti efektif menurunkan volume jaringan adiposa yang diujikan pada tikus yang obesitas. transdermalpatchcurcumin efektif digunakan sebagai anti obesitas (Ariamoghaddam et al., 2018). Penelitian tersebut memungkinkan penghantaranbiji salak sebagai bioadsorben lipid dalam sediaan transdermalpatch juga dapat efektif terhadap penanganan obesitas dengan mekanisme adsorben karena adanya kemampuan bioadsorben selulosa dalam biji salak. Serbuk simplisia maupun ekstrak biji salak juga mengandung senyawa tanin, monoterpen,sesquiterpen, polifenol dan alkaloid(Wahyuni dkk., 2017; Purwanto dkk., 2015). Kandungan monoterpen dan sesquiterpenpada biji salak merupakan turunan senyawa terpen, yang dapat berfungsi sebagai bahan penetrasi yang cocok digunakan dalam sediaan transdermal(Suwalie \& Mita, 2017). Review mengenai kemampuan bioadsorben lipid patch biji salak dalam terapi obesitas belum pernah dilakukan.

Adanya potensi bioadsorben lipid biji salak dalam sediaan transdermalpatch untuk terapi obesitas dan belum adanya review mengenai hal tersebut, melatar belakangi review yang kami lakukan. Reviewini mencakup halhal yang berkaitan dengan kemampuan dan efektifitasbioadsorben lipid dalam transdermalpatch biji salak sebagai terapi obesitas. Review ini bertujuan untuk menghasilkan artikel review yang membahas potensi bioadsorben lipid biji salak dalam sediaan transdermalpatch untuk terapi obesitas, sehingga dapat menambah nilai guna biji salak dan dapat bermanfaat dalam pengembangan dibidang kesehatan khususnya dalam bidang farmasi dan kedokteran.

\section{METODE}

\section{Strategi Pencarian Data}

Penelusuran data ini dilakukan berdasarkan beberapa strategi pencarian data yang dilakukan oleh Zahra dan Iskandar (2015) serta Joshua dan Sinuraya (2018)dalam artikel reviewnya.Pencarian data dilakukan dengan menelusuri berbagai database 
$\begin{aligned} & \text { seperti textbook farmasi } \\ & \text { maupunkedokteran tentang } \\ & \text { Google } \\ & \text { obsitas, } \\ & \text { Scholar, }\end{aligned}$
penelitian yang berkaitan dengan
kemampuan dan efektifitasbioadsorben
lipid biji salak dalam sediaan
transdermalpatchsebagai terapi untuk
obesitas, menggunakan kata kunci yang
terkait, seperti phytochemicalof
simplisia
andextractSalaccazalaccaseed,bioadsor

andextractSalaccazalaccaseed,bioadsor

benlipid biji salak,bioadsorbentlipid ofSalaccazalaccaseed,selulosa biji

salak, celluloseofsalaccaseed,

bioadsorbentlipid

ofcellulose,bioadsorbentcholesterolofcel

lulose, dan

transdermaldrugdeliverysystemofcholest

erol

dan

transdermalpatchforobesity.Referensi

data yang diperoleh kemudian

ditetapkan berdasarkan kriteria eksklusi dan inklusi.

\section{Kriteria Eksklusi dan Inklusi}

Penetapankriteriainklusidariartik

eliniadalah

data

berupatextbookfarmasimaupunkedoktera ndanjurnalbaiknasionalmaupuninternasi onal yang

membahastentangkandungansenyawabij isalak(Salaccazalacca)

khususnyaselulosa dapatberperanaktifsebagaiadsorbenterha dap lipid danpenggunaan transdermal patch

untukterapiobesitasmaupunkolesterol, denganmengutamakan data diatastahun 2014. Sedangkan, data yang termasukkriteriaeksklusiadalah data yang terkaitmaupun tidak terkait dengan kriteriainklusiserta dipublikandi bawahtahun 2015. Adapunsumber data yang tidak valid misalnyadata yang tidakmemilikitahunterbitantahun

volume dannomorpadaartikel.

\section{Studi Yang Digunakan}

Berdasarkan penelusuran referensi dari berbagai database, diperoleh 18 referensi yang terdiri dari data kriteria inklusi dan eksklusi. Data yang digunakandalampenyusunanartikel review inidan tergolong dalam kriteria inklusi adalah11referensi, yang terdiri dari 10 jurnal dan 1 prosiding.

\section{HASIL DAN PEMBAHASAN}

\section{Bioadsorben Lipid Biji Salak}

Salak (Salaccazalacca) termasuk dalam angiospermae yaitu tumbuhan berbiji tertutup. Tumbuhan berbiji tertutup adalah tumbuhan yang memiliki biji dimana struktur dinding selnya kaku dan tersusun dari senyawa selulosa (Girsang dkk., 2015). Biji salak kaya akan karbohidrat, serat dan kelembaban. 
Karbohidrat adalah kandungan kimia utama pada biji salak yang terdiri dari $28,98 \%$ selulosa dan $59,78 \%$ glukomanan(Kumoroet al., 2020). Berdasarkan penelitian yang telah dilakukan oleh Rosida dkk., 2018, kopi biji salak memiliki beberapa kandungan seperti protein, mineral, lemak, selulosa, pati, karbohidrat dan masih banyak lagi(Rosida dkk., 2018). Hal ini juga didukung oleh penelitian yang telah dilakukan oleh Lestari dkk., 2017, yang menyatakan bahwa semakin banyak serbuk biji salak dalam kopi biji salak maka semakin tinggi total karbohidrat produk tersebut. Hal ini dikarenakan kandungan utama dari bubuk biji salak adalah selulosa. Berdasarkan hasil uji, karbohidrat yang diperoleh dari serbuk biji salak adalah 78,41\%(Lestari dkk., 2018). Ekstrak biji salak dapat digunakan sebagai adsorben (Joshua dan Sinuraya, 2018). Selulosa dan senyawa aktif yang terkandung dalam biji salak ini memungkinkan biji salak dapat dijadikan sebagai biosorben (adsorben). Serbuk biji salak dapat digunakan sebagai bioadsorben terhadap minyak jelatah. Penyerapan warna yang lebih jernih merupakan hasil penyerapan minyak jelatah dari berat serbuk biji salak 20 gram yang dibandingkan dengan bioadsorben biji salak 5 gram dan 15 gram. Bioadsorben sebanyak 20 gram lebih efektif menyerap kolesterol dan trigliserida pada minyak jelatah dibandingkan berat serbuk biji salak yang lain. Selain itu, kadar malondialdehida (MDA) terendah juga berasal dari 20 gram biji salak. Serbuk biji salak bekerja maksimum dalam mengikat MDA pada minyak jelatah. Namun kadar MDA tersebut sedikit lebih tinggi dibandingkan dengan minyak baru yakni $31,8 \%$. Kadar MDA dipengaruhi oleh kadar peroksida lipid, yang secara tidak langsung peningkatannya menunjuk- kan tingginya jumlah radikal bebas. Meningkatnya berat biosorben menambah efektifitas pada daya kerja biosorben dalam menurunkan kadar MDA. Adanya sisi aktif pada biosorben biji salak tersebut bekerja maksimum dalam mengikat gugus fungsi yang terdapat pada minyak jelatah. Besarnya total luas permukaan pada biosorben memberikan peran yang cukup signifikan dalam memperkecil kadar LDL dalam minyak jelatah(Girsang dkk., 2015;Waluyo dkk., 2020).Selulosa mempunyai potensi yang cukup besar untuk dijadikan sebagai adsorben karena gugus $-\mathrm{OH}$ yang terikat pada selulosa. Biji salak mampu menyerap partikel koloid pada minyak jelatah(Ihwan dkk., 
2019). Hal ini juga didukung oleh penelitian yang telah dilakukan oleh Wulandari dan Dewi 2018, yang menyatakan bahwa kualitas minyak goreng bekas dapat meningkat karena adanya gugus fungsi $-\mathrm{OH}$ yang memungkinkan terjadinya interaksi dengan dengan asam lemak dan peroksida, sehingga mengakibatkan bilangan asam dan bilangan peroksida menurun. Selulosa memiliki pori yang dapat menyerap molekul yang ukurannya besar maupun kecil(Wulandari dan Dewi, 2018). Selulosa kaya akan gugus hidroksil ($\mathrm{OH})$ yang bersifat elektronegatif (basa) dan polar, sehingga dapat berinteraksi dengan gugus karboksilat (-COOH) dari freefattyacid (FFA) yang bersifat elektropositif (asam) dan polar. Senyawa peroksida dalam minyak mengandung gugus yang bersifat polar sehingga mudah diserap oleh gugus hidroksil dari selulosa yang bersifat polar(Ma' rifah dkk., 2018).Selulosaadalahsalahsatupenyusun dasarlignoselulosabahan yang banyakdigunakansebagaiadsorben.

Selulosamemilikisifatfisikokimia yang khasmemilikidayaserap yang kuatsehinggamembuatnyamenjadipenye rap(Suhas et al., 2016). Biosorben perlu didelignifikasi yaitu proses penghilangan gugus lignin dari kompleks selulosa agar tidak menutupi sisi aktif $-\mathrm{OH}$ selulosa. Adsorpsi secara fisika dapat terjadi karena beberapa atom $\mathrm{O}$ pada peroksida dan asam lemak bebas mengalami ikatan hidrogen dengan atom $\mathrm{H}$ pada pada gugus hidroksi selulosa (Royana dkk., 2018).

\section{TransdermalPatch Biji $\quad$ Salak Terhadap Obesitas}

Berdasarkan studi literatur yang telah dilakukan, terdapat beberapa penelitian mengenai efektivitas transdermalpatch dalam penanganan obesitas dan hiperlipidemia. Sistem terapi secara transdermal, merupakan sistem penghantaran obat melalui kulit menggunakan patch. Sistem tersebut dapat mencegah zat aktif yang berkhasiat obat mengalami metabolisme lintas pertama di hati, pelepasan zat obat terkontrol, durasi kerja obat lama serta pengaplikasiannya dapat dilakukan sendiri oleh pasien dengan mudah, selain itu dapat digunakan oleh pasien yang tidak sadar dan pasien yang tidak dapat menggunakan obat secara oral (Ghuladex and Verma, 2020). Berdasarkan penelitian yang telah dilakukan oleh Ariamoghaddam et al. 2018 , sistem penghantarancurcuminsecara 
transdermalpatch terbukti efektif menurunkan volume jaringan adiposa yang diujikan pada tikus yang obesitas(Ariamoghaddam et al., 2018). Selain itu, berdasarkan penelitian yang telah dilakukan oleh Shehata et al. 2018, transdermalpatch yang mengandung antihiperlipidemiaatorvastatin terbukti lebih efektif dari pada pemberiannya secara oral, yang ditandai dengan penurunan kadar kolesterol total, trigliserida dan LDL secara signifikan pada tikus yang hiperlipidemia(Shehata et al., 2018). Adanya kemampuan biji salak sebagai bioadsorbenterhadap minyak jelatah(Girsang dkk., 2015; Waluyo dkk., 2020) dapat menggambarkan potensi biji salak untuk dijadikan adsorben terhadap profil lipid pada penderita obesitas secara transdermal menggunakan patch. Potensi bioadsorben lipid transdermalpatch biji salak sebagai terapi obesitas didukung oleh penelitian sebelumnya terkait efektifitastransdermalpatch terhadap anti obesitas dan antihiperlipidemia, yaitu penelitian yang telah dilakukan oleh Ariamoghaddam et al. 2018, mengenai efektifitas curcumin sebagai anti obesitas dalam transdermal patch terhadap tikus yang obesitas dan penelitian Shehata et al. 2018, terhadap transdermalpatchantihiperlipidemiaatorv astatinyang efektif menurunkan kadar kolesterol total, trigliserida dan LDL pada tikus yang hiperlipidemia.

\section{KESIMPULAN}

Biji salak mengandung selulosa yang dapat digunakan sebagai adsorben. Selulosa mempunyai potensi yang cukup besar untuk dijadikan sebagai adsorben karena adanya gugus hidroksil $(-\mathrm{OH})$ sehingga dapat berinteraksi dengan komponen adsorbat dalam profil lipid seperti, kolesterol total, trigliserida, malondealdehida (MDA), LDL, asam lemak bebas, dan bilangan peroksida.Sistem terapi secara transdermal, merupakan sistem penghantaran obat melalui kulit menggunakan patch. Beberapa penelitian telah membuktikan bahwa transdermalpatch dapat digunakan dalam terapi obesitas dan lebih efektif dibandingkan rute oral pada terapi antihiperlipidemia.

\section{REFERENSI}

Adisesa, H. T. 1993. Beberapa Perubahan Struktur Dalam Selulosa Pada Pengeringan. Tesis Magister Kimia. Institut Teknologi Bandung, Bandung.

Aji, B. K. dan Kurniawan, F. 2012. Pemanfaatan Serbuk Biji Salak (Salacca zalacca) sebagai Adsorben 
$\mathrm{Cr}(\mathrm{VI})$ dengan Metode Batch dan Kolom.Jurnal Sains Pomits. 1 (1):1-6.

Ariamoghaddam, A. R., Hosseinzadeh, B. E., Zarmi, A. H. and Sahraeian, R. 2018.In Vivo Anti-Obesity Efficacy of Curcumin Loaded Nanofibers Transdermal Patches in High-Fat Diet Induced Obese Rats.Materials Science and Engineering C. 92 (2018):161-171.

Budiarso, F.,Budiarso, N., Ottay, R. dan Pontoh, W. 2019. IPTEKS Penyuluhan Tentang Obesitas dan Pengukuran Indeks Massa Tubuh Pada Masyarakat Kelurahan Malendeng Kecamatan Paal 2 Kota Manado.Jurnal Kedokteran

Komunitas Dan Tropik. 6 (2):281283.

Ghulaxe, C. and Verma, R. 2020. A Review on Transdermal Drug Delivery Systems.The Pharma Innovation Journal.4 (1):37-43.

Girsang, E. Kiswandono, A.A., Aziz, H., Chaidir, Z. dan Zein, R. 2015. Serbuk Biji Salak (Salacca zalacca) Sebagai Biosorben Dalam Memperbaiki Kualitas Minyak Goreng Bekas.Prosiding Seminar Nasional Pendidikan Sains (SNPS) 2015, 19 November 2015, Surakarta, Indonesia. pp.583-594.

Ihwan, Fadlia dan Anam, S. 2019. Mutu Minyak Jelantah Dengan Adsorben Biji Salak (Salacca zalacca(Gaertn.)Voss)

Menggunakan Parameter Bilangan Peroksida dan Asam Lemak Bebas.Jurnal Farmasi Galenika (Galenika Journal of Pharmacy). 5 (2):124-131.

Joshua dan Sinuraya, R. K. 2018.
Review Jurnal: Keanekaragaman Aktivitas Farmakologi Tanman Salak (Salacca zalacca).Farmaka. 16 (1): 99-107.

Karta, I. W., Susila, L. A. N .K .E., Mastra, I. N. dan P. G. A. Dikta. 2015. Kandungan Gizi Pada Kopi Biji Salak (Salacca zalacca) Produksi Kelompok Tani Abian Salak Desa Sibetan Yang Berpotensi Sebagai Produk Pangan Lokal Berantioksidan Dan Berdaya Saing.Jurnal Virgin. (2):123-133.

Kumoro, A. C., Alhanif, M. and Wardhani, D. H.2020. Review Article: A Critical Review on Tropical Fruits Seeds as Prospective Sources of Nutritional and Bioactive Compounds for Functional Foods Development: A Case of Indonesian Exotic Fruits. International Journal of Food Science. 2020 (2017):1-15.

Lestari, D., Kadirman, dan Patang. 2018. Subtitusi Bubuk Biji Salak Dan Bubuk Kopi Arabika Dalam Pembuatan Bubuk Kopi.Jurnal Pendidikan Teknologi Pertanian. 3 (1):15-24.

Ma' rifah, Jamaluddin, Yuyun, Y. dan Widodo, A. 2018. Pengaruh Penambahan Aktivator Dalam Pembuatan Karbon Aktif Ampas Tahu Sebagai Adsorben Minyak Jelatah. Kovalen. 4 (1):88-97.

Purwanto, N., Rismawati, E. dan Sadiyah, E. R. 2015. Uji Sitotoksik Ekstrak Biji Salak (Salacca zalacca (Gaert) Voss) Dengan Menggunakan Metode Brine Shrimp Lethality Test (BSLT).Prosiding Penelitian SPeSIA Unisiba Prodi Farmasi. Bandung, Indonesia. pp.616-622. 
Rosida, D. F., Happyanto, DC., Anggraeni, F. T. dan Hapsari, N.2018. Produksi Kopi Biji Salak Bangkalan Dengan Mesin Pemecah Biji Efisiensi Tinggi. Reka Pangan. 12(1):83-85.

Royana, I., Kurniawan, R., Yulianti, E. dan Mahmudah, R. 2018. Pemanfaatan Biosorben Batang Jagung Teraktivasi Asam Nitrat dan Asam Sulfat untuk Penurunan Angka Peroksida - Asam Lemak Bebas Minyak Goreng Bekas.Alchemy. 5 (1):10-18.

Shehata, T. M., Mohafez, O. M. M. and Hanieh, H. N. 2018. Pharmaceutical Formulation and Biochemical Evaluation of Atorvastatin Transdermal Patches. Indian Journal of Pharmaceutical Education and Research, 52 (1):54 61.

Suhas, Gupta, V. K., Carrott, P. J. M., Singh, R., Chaudhary, M. and Kushwaha. 2016. Cellulose: A Review as Natural, Modified and Activated Carbon Adsorbent.Bioresource Technology. 216 (2016):1066-1076.

Suwalie, E. R. and Mita, S. R. 2017. Terpen Sebagai Peningkat Penetrasi Pada Sediaan Transdermal.
Farmaka, 15 (3):102-110.

Tjay, T. H dan Rahardja, K. 2015. Obatobat Penting: Khasiat, Penggunaan dan Efek-efek Samping. Edisi ke VII. Elex Media Komputindo. Jakarta.

Wahyuni, L., Purwanti, L. dan Syafnir, L. 2017. Uji Aktivitas Antibakteri Ekstrak Bertingkat Biji Salak (Salacca zalacca varietas zalacca (gaert.) Voss Terhadap Stapylococcus aureus dan Eschericia coli. Prosiding Farmasi. Bandung, Indonesia. pp.229-230.

Waluyo, U. Ramadhani, A., Suryadinata, A. dan Cundari, L. 2020. Review: Penjernihan Minyak Goreng Bekas Menggunakan Berbagai Jenis Adsorben Alami. Jurnal Teknik Kimia. 26 (2):70-79.

Wulandari, W. T. dan Dewi, R. 2018. Selulosa Dari Ampas Tebu Sebagai Adsorben Pada Minyak Bekas Penggorengan.Kovalen. 4 (3):332339.

Zahra, S. dan Iskandar, Y. 2015. Review Artikel: Kandungan Senyawa Kimia dan Bioaktivitas Ocimum Basilicum L. Farmaka. 15 (3):143152. 

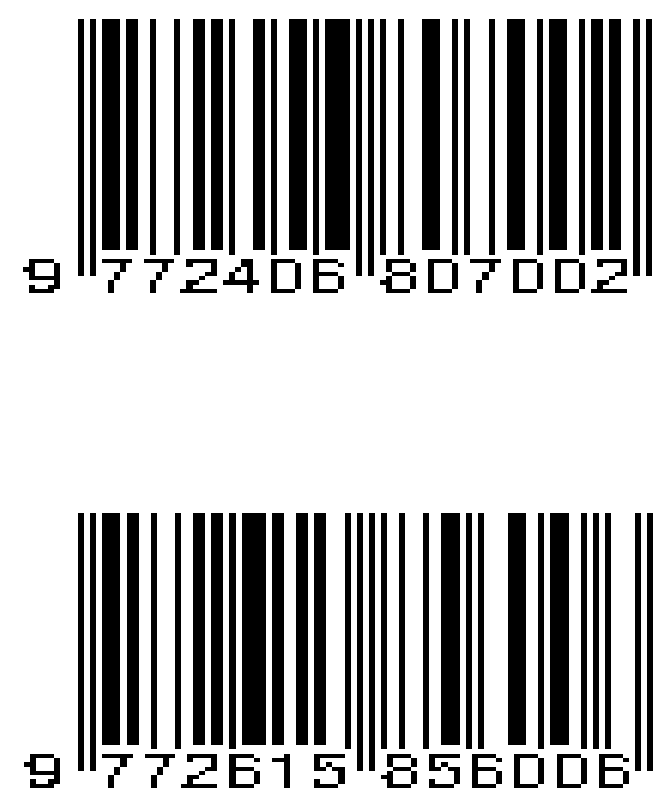